\title{
Disorientating, fun or meaningful? Disadvantaged families' experiences of a science museum visit
}

Article

Accepted Version

Archer, L., Dawson, E., Seakins, A. and Wong, B. (2016) Disorientating, fun or meaningful? Disadvantaged families' experiences of a science museum visit. Cultural Studies of Science Education, 11 (4). pp. 917-939. ISSN 1871-1510 doi: https://doi.org/10.1007/s11422-015-9667-7 Available at https://centaur.reading.ac.uk/70031/

It is advisable to refer to the publisher's version if you intend to cite from the work. See Guidance on citing.

To link to this article DOI: http://dx.doi.org/10.1007/s11422-015-9667-7

Publisher: Springer

All outputs in CentAUR are protected by Intellectual Property Rights law, including copyright law. Copyright and IPR is retained by the creators or other copyright holders. Terms and conditions for use of this material are defined in the End User Agreement.

www.reading.ac.uk/centaur 
Central Archive at the University of Reading

Reading's research outputs online 
This preprint copy is an accepted manuscript of the paper published in Cultural Studies of Science Education. Please cite as:

Archer, L., Dawson, E., Seakins, A. and Wong, B. (2016). Disorientating, fun or meaningful? Disadvantaged families' experiences of a science museum visit. Cultural Studies of Science Education. Online First.

http://download.springer.com/static/pdf/478/art\%253A10.1007\%252Fs11422-015-96677.pdf?originUrl=http\%3A\%2F\%2Flink.springer.com\%2Farticle\%2F10.1007\%2Fs11422-0159667-

7\&token $2=\exp =1456138771 \sim$ acl $=\% 2$ Fstatic $\% 2$ Fpdf $\% 2$ F $478 \% 2$ Fart $\% 25253 \mathrm{~A} 10.1007 \% 25252$ Fs11422-015-9667-

7.pdf\%3ForiginUrl\%3Dhttp\%253A\%252F\%252Flink.springer.com\%252Farticle\%252F10.10 07\%252Fs11422-015-9667-

7* hmac=bfaf2331b0f20bf4fb250fb9806d1a69f5b9d616818746ed132d8ad8527078cc

\title{
Disorientating, fun or meaningful? Disadvantaged families' experiences of a science museum visit
}

\section{Louise Archer, Emily Dawson, Amy Seakins and Billy Wong}

Keywords Diverse families· museums· inclusion· Bourdieu

\begin{abstract}
It is widely agreed that there is a need to increase and widen science participation. Informal science learning environments (ISLEs), such as science museums, may provide valuable spaces within which to engage visitors - yet the visitor profile of science museums remains narrow. This paper seeks to understand the experiences of socially disadvantaged families within such spaces. Using a Bourdieusian analytic lens, we analyse qualitative data from a small study conducted with 10 parents and 10 children from an urban school who visited a large science museum. Data includes pre- and post-interviews, audio recordings and visit fieldnotes. We characterised families' experiences as falling into three discourses, as 'disorientating', 'fun' or 'meaningful' visits. Analysis identifies how the families' experiences, and the likelihood of deriving science learning from the visit, were shaped through interactions of habitus and capital. Implications for improving equity and inclusion within ISLEs are discussed.
\end{abstract}

\section{Archer}

Department of Education and Professional Studies, King's College London, Waterloo Road, London SE1 9NH, UK.

Email: Louise.archer@kcl.ac.uk 
Internationally, governments and science educators have expressed concern that science participation needs to be increased and/or broadened for reasons of both national economic competitiveness (ensuring an adequate supply of appropriately trained STEM professionals in key shortage areas) and social justice (ensuring that STEM fields are open to all). The issue is particularly acute in the case of the physical sciences where, as Emma Smith (2010) has argued in the context of the UK, the profile of a 'typical' graduate remains white, male and middle-class. As the AAUW (2010) report discusses, such patterns have also been found in the USA. These patterns persist despite decades of interventions aimed at broadening the profile of scientists in university and beyond.

It is often argued that Science, Technology, Engineering and Mathematics (STEM) industries are seen as crucial for national economic growth and competitiveness (e.g. CBI 2012). For example, the European Commission report by José Gago (2004), declares in its title that 'Europe needs more scientists'. In the UK, such concerns are currently heightened as several sectors are either currently experiencing, or are predicting, significant STEM skills gaps, due to a lack of appropriately qualified applicants (Wilson 2009). Hence the government (e.g. Department for Education and Skills 2004) and industry (e.g. UK Comission for Employment and Skills 2010) are particularly keen to increase science participation.

It is also widely agreed that ensuring that the population has a good level of scientific literacy (understanding of science) is also very important (Irwin and Michael 2003). Increased scientific literacy is not only good for the economy, but can also benefit individuals and communities economically and socially, helping to promote active citizenship and enabling people to participate in, and shape, scientific and technological developments in society. Peter Elias and Jones (2006) found, however, that the profile of those who do go on to study STEM subjects and pursue STEM careers remains narrow, with women, working-class and some minority ethnic groups being under-represented, especially in the physical sciences and engineering. In other words, the question of how to better engage young people and citizens with science, and improve science learning and participation, is a key national concern.

There is a rich body of work that shows how 'Others' (e.g. female, working-class, minority ethnic) people feel excluded from the normative culture of science. For instance, Sandra Harding (1998) discusses how women and minority ethnic groups may be marginalised by mainstream science. Evidence suggests that museums and informal science learning environments (ISLEs) can play an important role in helping to engage and inspire people with science (Bell, Lewenstein, Shouse and Feder 2009) and can be important vehicles for promoting 
science learning, as the review by Falk et al. (2012) discusses. Informal learning environments are defined by Bell et al. (2009, p. 1) as including:

a broad array of settings, such as family discussions at home, visits to museums, nature centers or other designed settings, and everyday activities like gardening, as well as recreational activities like hiking and fishing, and participation in clubs.

It is important to note that while people are able to engage with and learn about science almost anywhere, the ISLEs we focus on here are designed environments, such as museums and science centres, rather than private/ domestic spaces.

John Falk and Lynn Dierking (2010) suggest that ISLEs provide valuable opportunities for people to engage with science across the life-span, in ways that are at least as important as school experiences, if not more so. ISLEs have been shown to help visitors learn about scientific content. For example, a study by Bamberger and Tal (2008) of 13-14 year-old students visiting a science centre in Israel demonstrated that learning from the visit was still evident when students were re-interviewed 16 months later. Although studies into learning science in informal environments have traditionally focused on cognitive learning, other impacts have also been identified, including affective (Packer and Ballantyne 2004) and social impacts (Leinhardt, Crowley and Knutson 2002). It has also been argued that ISLEs may provide opportunities for learners to link scientific content to their everyday lives (Zimmerman, Reeve and Bell 2010). Yet it is commonly agreed, as discussed by Falk et al. (2012), that the sector requires more robust and extensive evidence of these benefits.

Existing data on participation in ISLEs shows that science museums (and those attending a range of science-related extra-curricula activities, as detailed in surveys such as IPSOS MORI 2011) traditionally record a relatively narrow visitor demographic, primarily attracting middle-class, urban families, from the dominant ethnic background, which in Europe (OECD 2012) and the United States and Canada (Bell et al. 2009) typically means white, city-dwelling families.

There is a comparatively small literature that focuses on issues around equity, inclusion and museum education. For instance, work by Amy Levin (2010) on gender, sexuality and museums and by Richard Sandell (2007) and Sandell, Dodd and Garland-Thomson (2010) on disability suggest that museum environments are structured in various ways that disadvantage people by failing to take 'difference' into account. Research on equity, inclusion and ISLEs by Doris Ash (2004) and Fernando Garibay (2009) has found that minority ethnic groups' opportunities for science learning are limited by dominant language practices and Western, ethnocentric representations of both science and people represented within science exhibits 
(British Science Association, 2006; Garibay, 2009). Research on gender by Minda Borun (1999) and Linda Ramey-Gassert (1996) also suggests that, despite earlier assumptions that ISLEs might afford less gendered science learning opportunities than school classrooms, this is not necessarily the case.

This paper reports on data that were collected as part of a larger, five year study (the Enterprising Science project, conducted in partnership between King's College London, the Science Museum and funded by BP), which aims to help more students to find science engaging and useful for improving their life chances. The wider project seeks to build 'science capital' (Archer, DeWitt and Willis 2013) among young people, families and schools, through partnership working between museums and schools. In particular, the project aims to find more equitable ways to connect science and young people's lives and, in particular, to increase disadvantaged young people's science-related engagement, resources and identities. The data discussed in this paper were collected at the start of the project, with the aim of trying to increase our understanding of the barriers to inclusion that disadvantaged families may experiences within ISLE spaces, such as a science museum.

This paper seeks to contribute new knowledge about how disadvantaged groups engage with science museums. We use a sociological theoretical approach to generate concepts and ways of understanding the barriers to, spaces for and inclusion of disadvantaged families. The paper reports data from a small-scale exploratory case study, conducted at the start of the wider project, with 5 families from one urban school and asks: how did these families experience their (first) visit to a science museum? What hindered or facilitated their engagement? What did they 'learn'?

\section{Theoretical framework}

Our conceptual framework draws on two main bodies of work: (i) feminist post-structuralist theorisations of identity and (ii) Pierre Bourdieu's theorisation of social reproduction.

We draw on feminist poststructuralist theorizations of identity to understand individuals' identifications with science the extent to which they see science (and informal science learning contexts, such as museums) as being 'for me'. This approach includes Judith Butler's (1990) theorizations of identity as 'performance' and integrates it with a conceptualization of identity as intersected, and mediated, by social axes, such as 'race'/ethnicity and social class (Barton and Brickhouse 2006). We build on Floya Anthias' (2001) conceptualisation of identity as nonessentialised, fluid, contested and produced through discourse. That is, identity is something that we 'do' - not something we just 'are'. As Stuart Hall (1990, p.222) explains, identities are always 
'in process', being constituted within and through discourse and relations of power. Social structures (e.g. of gender, class, 'race') all contribute to shaping the spaces, identities, choices and aspirations that people perceive as being potentially 'for me'.

Extending the notion of identity to our focus on engagement with science and experiences of science museums, we also use the concept of 'science identity', as articulated by Carlone and Johnson (2007), in which science identity refers to both an individual's sense of self (as someone who is interested in and/or competent at science) and the extent to which they are recognised in this way (as being talented/ having potential in science) by others. That is, science identity captures the extent to which a person sees themselves, and is recognised by others as being, a viable science subject. As research has shown, tensions between student and institutional and/or disciplinary identities (Brickhouse, Lowery, and Schultz 2000) can impact on a young person's ability to learn and participate in school science (Barton and Tan 2009) and in this paper, we consider the extent to which a visit to a science museum might influence (or not) the development, reinforcement or erosion of adults' and young people's 'science identities'.

The second pillar of our conceptual framework draws on the work of Pierre Bourdieu (e.g. Bourdieu and Passeron 1990), which addresses the reproduction of social inequalities in society. In particular, Bourdieu argues that relations of privilege and domination are produced through the interaction of habitus, capital and field. Habitus refers to a set of attitudes, expectations and experiences that shape how a person operates in the social world. As Diane Reay (2004) explains, habitus can be conceptualised as an inner matrix of dispositions which shape how the individual understands and makes sense of the social world. Habitus provides people with a practical 'feel' for the world. It is shaped by both an individual's own history and the wider collective experiences of those from similar backgrounds/ social groups, for example in terms of gender, 'race'/ethnicity, social class and other social axes. It is through habitus that the individual has an (often implicit) understanding of 'what is normal for people like me', a set of dispositions that frame ways of thinking, feeling and being and which thus guide current and future actions and possibilities.

Bourdieu conceptualised habitus as encompassing both individual and collective formations, such as gendered habitus and classed habitus. Various writers have worked productively with collective notions of habitus, such as institutional habitus (e.g. Reay, David and Ball 2001), collective class habitus (e.g. Charlesworth 2000) and 'family habitus' (Archer et al. 2012). Indeed, Reay argues that a 'collective understanding of habitus is necessary, according to Bourdieu, in order to recognize that individuals contain within themselves their past and present position in the social structure' (Reay 2004, p.434). In this paper, we draw particularly on notions 
of institutional habitus - in order to understand the institutional 'culture' (e.g. tacit knowledges and taken-for-granted 'normal' ways of being) within museums - and family habitus:

... family habitus is used to explore the extent to which families construct a collective relationship with science and the extent to which this is shaped by their possession of particular sorts of economic, social and cultural capital. In particular, we examine participants' accounts of how science is 'woven' into un/conscious family life (or not). (Archer et al. 2012)

Family habitus may represent an important locus for the reproduction of dispositions towards, or equally against, participation in science, science career aspirations, interest in science hobbies or pursuits and ISLE visiting. Families comprise a significant visitor group for ISLEs and research suggests their interactions during ISLE visits can play a significant role in both affective and cognitive learning (Zimmerman, Reeve and Bell 2010). In terms of developing formative dispositions around science therefore, family habitus may play an important part in whether a person develops 'science capital' or not.

Capital is used to denote the different resources that can be drawn on, which can be economic, cultural, social and symbolic. In this paper, we utilise a theorisation of 'science capital' to help us understand the production of different patterns between individuals and families in terms of their ability to access and leverage science learning and value from a visit to a science museum. We have described 'science capital' in more depth elsewhere (Archer, DeWitt and Willis 2013), here we use the concept to describe the social, cultural, economic or symbolic resources related to science that people have at their disposal. Such resources may help them navigate complex scientific texts, understand pathways into science careers or pursue sciencebased hobbies. We are particularly interested in whether accruing science capital may help people change the social reproduction of disadvantage through the realisation of the exchange value of their science capital in society.

\section{Methodology}

This small-scale, exploratory, case-study adopted a qualitative design, using (pre- and post-) focus groups and interviews with students, pre and post interviews with parents and observation of families during their visit. As stated above, the study described in this paper was a small-scale case study which formed the initial, exploratory round of research for Enterprising Science, an on-going, five-year project. The element of the study reported here focused on one of the 21 schools involved in the study and sought to explore in detail the ISLE experiences of five families, recruited from one class in that school. The study conceptualised schools as key 
community hubs or gatekeepers, from which the science learning experiences, science attitudes and science career aspirations of students and their families could be explored. The museum that participants visited was one of four ISLEs participating in the study. It was chosen on the basis that it is a large national science museum which seeks to engage visitors from a wide range of backgrounds. One of the museum's aims is to help visitors to understand the relevance of science within everyday life. These initial family visits were intended to provide a 'baseline' experience from which to learn more about potential barriers to engagement and to then inform the later development of new approaches and ways for ISLEs to engage diverse families and to improve connections with school science learning.

Schools were approached to participate in this study following a sampling framework that aimed for 'middling' schools and sought to avoid extremes of high or low attainment, student numbers, funding, and so on. Thus schools were recruited on the basis that they were state-run, mixed in terms of gender and were within $\pm 20 \%$ of their local average in terms of General Certificate of Secondary Education (GCSE) (the national examinations taken by students at the end of compulsory schooling, age 16) exam achievement (5 A*to C in 2011). Schools were also selected on the basis of having medium to high proportions (compared to their local authority average) of students eligible for free school meals (often used as a proxy measure for social disadvantage) and who spoke English as a second language. Furthermore, schools were not selected if they had been involved in projects with our partner ISLEs.

For the wider project we recruited 20 schools across London, Manchester, Bradford and York. In this paper we focus on the experiences of students and their families from Mareton School, one of the inner-city London schools in the study. Recent government data indicates that $53 \%$ of students at Mareton School are eligible for free school meals and 54\%, speak English as a second language. The school achieves generally lower (around 10\%) results in national examinations compared to other schools in the local area. We recruited students from a mixedability year 7 science class (aged 11 and 12) and their families to take part in this exploratory study which sought to investigate their expectations and attitudes about ISLEs and their experiences during a visit to an ISLE. We distributed recruitment letters (via teachers) to students and their families and researchers attended a parents evening at the school to explain the project and answer questions. All recruitment materials, including initial introductory letters, information sheets, consent forms and follow-up invitations to the museum were also professionally translated into the home languages of students (including Polish, Portuguese and Turkish). We invited families to visit the museum over two different dates during the summer holidays and their travel and refreshments were arranged and subsidised by the ISLE. All 
arrangements for the visits were reiterated and confirmed during the parental telephone interviews.

Data were collected before, during and after the visits. Prior to their visits students were involved in two focus groups at school in the month before the visit and their parents were interviewed over the telephone a week in advance. Two sets of focus groups (4 in total) were carried out with students prior to the ISLE visit to explore their attitudes towards science at school, science career aspirations and whether they were involved in any science-related activities outside school. While the first focus groups concentrated on prior experiences and attitudes the second set explored students ideas and expectations about the upcoming ISLE visits. Focus groups were approximately 40 minutes long and included 4 or 5 participants in each group (total $n=12)$. Parental interviews were carried out in the week before the ISLE visits $(n=5)$. These were carried out by telephone after all parents agreed this was the best way to contact them. Interviews ranged from 15 to 45 minutes long and parents were asked about their children's experiences studying science at school, their family life, their career aspirations, their prior experiences of ISLEs and their expectations about the visits.

Of a class of 28 students at Mareton School, 8 families agreed to take part and 5 families ultimately participated in the ISLE visits (three families were unable to take part on the day due to illness or the lead adult not being able to take time off work). On the visit, families were observed by a researcher who made field notes and took photographs. One member of each family was also asked to wear a microphone to audio record the visit. Visits lasted between 2 and 5 hours. On arrival, families were welcomed by the Museum and research teams and received a brief orientation in a dedicated room/space with refreshments. Each family was provided a lanyard, with an outline of the activities suggested for their day visit. These included four drop-in facilitated sessions ('my object', 'pop-up workshop', 'object trail' and 'meet a scientist') and a visit to an interactive gallery. Apart from the suggested sessions on the lanyards (which were framed as voluntary) visits were self-led and participants were not given any further explicit instructions regarding how they should conduct their visits. Each family member was also provided lunch and drink vouchers, and a map of the museum. To conclude the visit, the focal child was given a 'goody bag' (of small museum gifts, experiments and a letter to claim IMAX tickets on their next visit).

Post-visit interviews were carried out with students and their parents. Parents were interviewed over the telephone in the month that followed the visit $(\mathrm{n}=3)$ and students were interviewed two to three months after their visit once they were back at school $(n=5)$. Focus groups, interviews and visit observations were conducted by two white-British, middle-class 
female researchers and one British-Chinese middle-class male researcher. Additionally a Turkish, middle-class, female researcher carried out the parental interviews with the Kurdish Turkish family. All data were audio recorded, transcribed and anonymised, visit observations were also recorded using field notes and photographs alongside audio recordings.

Five families from Mareton School visited the Museum over two consecutive days in August 2013. Family details are provided in Table 1. Focal students were all in Year 7 of school at the time of this research.

Table 1: Family background and composition.

\begin{tabular}{|l|l|l|l|}
\hline Ethnic background & Group size and composition & Focal Child & Focal Parent \\
\hline Turkish Kurdish & $\begin{array}{l}4 \text { (mother, father, and their } 2 \\
\text { children) }\end{array}$ & Esrin & Mr. Kaya (father) \\
\hline Mongolian & $\begin{array}{l}6 \text { (2 fathers (friends) and their 4 } \\
\text { children, aged 4, 8, 12, 15) }\end{array}$ & Bataar & Gan (father) \\
\hline White British & $\begin{array}{l}3 \text { (1 mother with son and his } \\
\text { friend) }\end{array}$ & Darren & Linda (mother) \\
\hline Black Caribbean & $\begin{array}{l}4 \text { (1 mother with son, Damis, and } \\
\text { his cousin and 'little uncle' } \\
\text { (younger than Damis) }\end{array}$ & $\begin{array}{l}\text { Damis } \\
\text { daughters) }\end{array}$ & Tanisha (mother) \\
\hline
\end{tabular}

Participant profiles

Esrin is positive about science in general, and the social aspects of school, which she describes as 'fun'. She lives with her mother, father and three siblings. Her parents do not work. Her family, Kurdish Turks, moved to London as refugees. Esrin had been to a small local museum with her primary school, and had once visited a small local museum with her family while on holiday in England.

Bataar enjoys school science, and particularly finding out about how things work, although his preferred subject is Maths. He lives with his mother and father and two brothers. His family are from Mongolia. His father works and mother does not. Bataar describes his parents as encouraging him to "to study hard for my GCSEs". Bataar has been to a large zoo and aquarium with his family previously and a large national art gallery with school. Bataar says 
he prefers zoos/ aquaria to museums. He would potentially like to have a career involving maths (e.g. accountancy), but is not totally sure.

Darren enjoys his school science lessons, in particular he likes the practical work and experiments, and would prefer less writing. Darren lives with his father, mother and two older brothers. His family are White British. Darren has been to a science museum before with his primary school, and has also visited a local city farm. Darren would like to be a footballer in the future.

Damis enjoys science, saying “it's like my best subject”. He lives at home with his mother and stepfather. His family are Black Caribbean. Damis had never been to a museum before participating in this research. Damis' future aspirations change frequently - including being a footballer and a banker.

Kayefi likes science at school and does well in the subject. She lives with her mother, father and two sisters. Her family are Muslim and from West Africa. Her father works at an embassy and her mother does tailoring work from home. Mr. and Mrs Ogwu are the only parents in the study who have science A-levels (Mr. Ogwu also has a BSc degree, but not in science). Kayefi has previously visited a zoo and a natural history museum with her family. She aspires to be a doctor, like her cousins.

Analysis

The initial analysis was undertaken by the lead author who, after initial sorting and coding of the data (by key topic areas), searched the data iteratively to develop a discursive typology of family visits. Through a literature-informed analysis of the data, three main 'types' of visit emerged, reflecting broadly negative/ problematic (one category) or positive (two categories) of family experiences on the visits. By moving back and forth between the data and literature, we developed a terminology for these visits as either 'disorientating' (visits that were in some way problematic or 'troubling'), 'fun' or 'meaningful'. The terminology of 'fun' was taken largely from participants' own accounts of the visits but the terminology of 'disorientating' and 'meaningful' was developed by researchers through the analytic process as 'best fit' labels to convey the essence of each categorisation. The term 'meaningful' was particularly informed by literature around equity and science education which promotes the value of cross-cultural learning and approaches to science learning that value less privileged groups' own cultural resources and understandings. The typology (and terminology) was refined through successive phases of coding and analysis, iteratively testing emergent themes across the data set to establish "strength" and prevalence (Miles and Huberman 1994). Codes were refined through discussion with the three other authors. The descriptive coded themes were then subjected to a 
Bourdieusian, theoretically informed analysis, to further delineate the different ways in which visits might be, for instance, 'disorientating'. For example, Bourdieusian analysis highlighted interplays of habitus and capital within families' 'disorientating' experiences of the museum visit and how disjunctures between family and institutional habitus created unease for participants and were implicated in positioning families as Other. Analysis using the study's 'identity' conceptual lens was then conducted to examine themes around 'belonging' and 'othering', to assess the extent to which families were included or positioned as Other within the institutional context and the implications of each of the different types of visit.

\section{'Disorientating' visits: the disjuncture between family and institutional habitus}

For all but one of our participants, this was their first family visit to the museum. Darren and his family had visited the museum before when he was younger and, unlike the others, they wanted to visit a specific gallery during their visit. All families reported enjoying their visit very much. However, as we shall argue, while enjoyment and 'fun' are undoubtedly important and valuable aspects to any visit, these do not necessarily equate with social inclusion or science learning.

We categorised the families' experiences as falling within three main discourses, which we shall now discuss in turn: 'disorientating' visits; 'fun/special days out'; and 'meaningful' visits. These types of visit were not mutually exclusive of one another, but as discussed below, characterised key aspects of the various families' experiences of the visit to a greater or lesser extent. As will be discussed, it is the latter type that we suggest are the most beneficial in terms of facilitating inclusion and science learning - yet it was also the least widely experienced form of visit and, we shall suggest, may depend upon families' possessing a particular level of capital and/or alignment between family and institutional habitus. In particular, we contend that the institutional habitus of the ISLE was classed in ways that favoured certain more middle-class practices and attitudes over others, thus where family habitus could not match the institutional habitus visits provided fewer opportunities for informal science learning.

Disorientating and overwhelming visits

To a greater or lesser extent, all families experienced some aspects of their visit as being somewhat disorientating and, at times, overwhelming. Moments of confusion and disorientation were amplified by the enormous space and scale of the museum. All participants experienced difficulty in navigating the layout of the museum and all got lost at various points, with researchers frequently being asked to step in to direct families to particular locations. As a frustrated Damis put it, “the map don't help”. Navigating a large and complex museum can be a 
challenge for many first-time visitors, but as we shall now discuss, the challenges may be amplified for families who lack familiarity with such institutions and who do not enjoy the same framework of dispositions and cultural capital that enables them to already know the tacit 'rules of the game'.

The 'disorientating' visit was most closely typified by the experience of Esrin and her Turkish Kurdish family. Although Esrin's family reported largely enjoyed their day out, their experience highlighted significant struggles with language and difficulties understanding the nature, lay out, organisation and habitus of the museum. Esrin and her family were shocked by the large size and scale of the museum, having previously visited one small, local museum.

Our observations recorded various examples in which each of the five families appeared to be unfamiliar with the unspoken 'rules of the game' within a museum setting. Using our Bourdieusian analytic lens, we interpret such moments as exemplifying a disjuncture between the family habitus and the institutional habitus. As Bourdieu (1998, p.80)writes, "having the feel for the game is having the game under the skin". In these moments, families were unfamiliar with the dominant expectations of what one 'does' (or does not do) within a museum visit. This was exemplified through mismatches in terms of understandings about what constitutes normal or 'proper' behaviour, knowledge and language within the museum.

Families felt disorientated and at a disadvantage because they did not know the dominant institutional 'rules of the game'. We also recorded examples of how some families were made aware of being a 'different' (Other) sort of visitor, for instance due to their ethnic and/or social class backgrounds. Fieldnotes recorded occasional instances where families appeared quiet or reserved when interacting directly with other white, middle-class facilitators or visitors. For example, Kayefi's family were polite but exceptionally quiet during a pop-up interactive and only made minimal replies to the (white, middle-class) facilitators. During the family's visit to a museum theatre show they also sat very quietly and appeared to be too shy to volunteer (despite trying to prompt one another). Feelings of difference were underlined when, entering the show, the facilitator on the door only spoke to the white researcher as a proxy for the whole family. One potential explanation was provided by Bataar, who in his post visit interview commented "it was like there was a lot of posh people, not really like other kind of races".

Judging right from wrong: behaviours, knowledges and assumptions.

In terms of behaviour, the disjuncture between family and museum habitus was illustrated by several parents' anxiety about their children touching exhibits in the galleries - even interactive ones. For example, when Esrin touched objects or activities in a number of galleries, her father urged "don't touch, don't touch". Most families seemed to be confused by (and not party to) the 
(often) unwritten rules as to what could, or could not, be touched. This confusion was evident when several families were told off by museum staff for touching the 'wrong' exhibits in particular galleries, instances which only served to fuel parents' anxiety as to whether touching was allowed, or not.

The mismatch between family habitus and institutional habitus was also exemplified by uncertainty over behavioural norms. Darren's family's experience in a history of medicine gallery was particularly illustrative. This was a dark and quiet gallery located on the top floor of the museum. As Darren said on entering the gallery, "shhh, it's a library". In her follow up interview, Linda commented that she had not enjoyed this gallery, mainly due to her anxiety that she "daren't say too much" in case they were reprimanded for behaving incorrectly/ inappropriately. The interviews and observations were peppered with examples in which the five families appear to experience the museum like a 'fish out of water' (Bourdieu and Passeron 1990). Family habitus for our participants did not include a "feel for the game" as Bourdieu (1998, p.80) put it, they could not second guess the implicit rules of the ISLE.

Families were not only Othered by not knowing dominant 'rules of the game' regarding appropriate museum behaviour, but also in terms of the institutional regulation of whose knowledge 'counts'. There were various examples in which Esin's family appeared to be unclear about the nature and purpose of particular activities. One particular instance occurred when Esrin and her family appeared to get frustrated with a facilitated activity that they took part in. The exercise was designed such that visitors explored a 'mystery' object from the ISLEs handling collection. The 'mystery' object activity was designed as an introductory activity to welcome families to the ISLE and introduce them to thinking about historic and scientific objects before embarking on their gallery visits. The activity was delivered by a staff member who sat with the family and facilitated a discussion about the object designed to help the family guess what the object was (in this case a hot water bottle - see image 1).

Esrin's father appears resistant to the explanation offered by the facilitator (that this is a hot water bottle), saying he used water bottles like this when he was young. He mentions a few times that he is 'older' and he 'knows what it is'. Towards the end of the activity, however, he begins to apologise profusely to the facilitator and researcher, explaining that he does not speak good English and that he does not understand (Fieldnotes). As noted in the fieldnotes, initially Mr Kaya tries to assert his own viewpoint as valid, but by the end of the interaction he acquiesces to the authority of the museum's dominant knowledge and explanation. As Bourdieu suggests, "the institution confers on professional discourse a status 
authority" (italics in original, Bourdieu and Passeron 1990, p.108), against which can subordinate 'other' claims to knowledge - leading to the exclusion of Others.

Language and social interaction.

The disjuncture between family and institutional habitus was also exacerbated and exemplified by issues of language. Language emerged as a key element of how difference was manifested and experienced by families, both in terms of class and ethnicity. For example, Linda (Darren's mother) showed an interest in a particular object in the history of medicine gallery. But she found the text very confusing. She commented "that must be a birthing stool" (which was correct) but she could not then understand the language that the caption text was written in, which referred to a 'parturition chair' and did not make any reference to childbirth or women (referring only to the views of male midwives). She consequently decided that she must have been wrong in her assumption. As Bourdieu argued, "the educational market is strictly dominated by the linguistic products of the dominant class and tends to sanction the pre-existing differences in capital"'(1991, p. 62). In this example the combination of institutional epistemic practices with dominant language practices meant that Linda, a native English speaker, was excluded by the scientific language used in the exhibit label. She was not only unable to learn from the exhibit, her pre-existing knowledge was undermined. In short, the linguistic and epistemic practices of the museum teach Linda that she is 'wrong'.

Issues of language were particularly salient in the case of Esrin's family, who were not native English speakers. Esrin's father was present throughout the visit but was unable to help or support his daughter during activities due to being 'disabled' by language and cultural capital barriers. As Esrin explained in her post-visit interview, “my dad doesn't know English that much ... so I was reading it to them". Again, the institutional habitus of the museum (as constructed by linguistic and epistemic practices embedded in exhibits, maps, facilitation styles and instructions), undermined the family's ability to access science learning opportunities or to understand the tasks that they were expected to perform.

As a result of her father being disadvantaged within the situation - because he does not possess dominant cultural and linguistic capital and his own cultural and linguistic capital is marginalised/ not valued by the field - Esrin often seemed unsure as to what she should be doing. For instance, she frequently checked with the researcher (as a presumed embodiment of dominant cultural knowledge and linguistic capital) as to whether they were doing the activities 'correctly' and what they should do next (e.g. asking “"what do we do now, do we collect information or something?"). The researcher noted how Esrin was quite dependent upon her for help and that her father was effectively sidelined in the activities, unable to help or contribute. 
Esrin's father raised his difficulty with language within the museum during his post-visit interview:

... my English is not sufficient.....You have to read when this event happened, yet I have no English. I cannot say much about it.

The institutional expectations embedded in the design of exhibits, trails and facilitated activities were that visitors would use museum tools to learn about science and history, with discussion as the principle medium for family learning. Social interaction in museums is widely seen as important in facilitating learning; conversations are seen as tools through which learning can be developed (Leinhardt, Crowley and Knutson 2002), questioning has been promoted as encouraging inquiry learning at exhibits (Ash 2003) and interactions with accompanying family or peers are ways in which learners can position themselves as 'experts' in their group (Crowley and Jacobs 2002). The institutional reliance on English meant that families (like Esrin's) with limited English language skills, particularly in terms of being able to read English, were unable to undertake 'learning conversations'. As Bourdieu explains, "Speakers lacking the legitimate competence are de facto excluded from the social domains in which this competence is required, or are condemned to silence" (1991, p. 55, italics in original). Thus, Esrin's father was doubly othered, unable to speak and, as a result, unable to learn through the idealised museum model of discussion-as-learning.

\section{Cultural capital.}

Language was not the area in which participants were disadvantaged due to their own cultural resources not being recognised/valued and, accordingly, being positioned by the field as not possessing the 'right' (dominant) forms of capital. A disjuncture between family habitus and institutional habitus also meant that families were positioned by the field as not possessing the 'appropriate' (required/ dominant) cultural resources to facilitate family learning. For instance, Gan (father of Bataar) directed their family visit and although his children explored most of the interactive and displays they walked past, the children were often 'rushed' to the next part of the museum by Gan. This resulted in some missed opportunities for engagement and potential reinforcement of Bataar's 'maths' identity. In the pre-interview, Gan noted that Bataar is really interested in mathematics and numbers and said that Bataar aspires to a maths-related future career. Yet when the family reached a mathematics-related section of the museum, Gan did not pick up on the mathematics theme and moved the family group on before Bataar had a chance to engage.

The mismatch between institutional and family habitus and capital meant that, for most of the families, self-led activities did not entirely work. For example, Bataar's family's 
engagement with a 'find the object' activity in one of the galleries did not really work as a learning activity. Once an object was found, family members 'high fived' and moved straight on to the next object, with no questioning or engagement over the content. The family worked as individuals, rather than collectively, with children splitting up to hunt down an object. The whole activity was completed within 5 minutes. This pattern was repeated among the other families. Consequently, we suggest that some of the families were unable to access meaningful or substantive science learning, thus reducing their potential to derive exchange value from the visits.

\section{'Fun/ special days out': use value but not exchange value?}

As noted earlier, all the families enjoyed their visits, which were characterised as 'fun' and 'special' days out. As Kayefi explained in her post-visit interview, 'it was nice seeing it. It's better than hanging at home. Yeah, better than going out to parties, it's better than that!" As we shall now discuss, three of the families (Darren's, Bataar's and Damis's) were particularly characteristic of this category. Families seemed to derive two main sources of value and pleasure from their visits: the opportunity it provided for family social bonding and its status as a 'special' day out.

Family time: social capital and family bonding.

In the pre-visit interview, Tanisha admitted that one of her main motivations for taking part was the opportunity to use the visit to bond and spend more time with her son, Damis. The value of spending 'quality time' with a parent or family was also noted by Damis and most of the other students in their post-interviews:

It's like a good thing, because me and my mum yeah ... we don't go out like together [...] So it was like ...it was like fun being around my mum (Damis)

It's interesting because ... well I've never had the chance to go ... and we've never really gone out as ... as an outing like that as a family. (Kayefi)

I got to spend the day with my family (Bataar)

Parents and children compared this rich, 'family time' to their usual 'time-poor' lives, which, as economically disadvantaged families, were characterised by the demands of working long hours and managing the household.

The pleasurable nature of the visits was underlined by the 'specialness' of the days which broke from normal routine and for which transport and refreshments had been arranged and paid for by the project. The families were also made visibly different ('special') from other visitors by virtue of wearing a special lanyard and being accompanied by a researcher who 
assisted, recorded and photographed them throughout their visit. Families also enjoyed a dedicated, reserved area in the museum, with free refreshments, seating and storage. For some children, the free food added particularly to the excitement of this special day out. As Darren reflected in his post-visit interview, "the best bit was the food!".

As Packer and Ballantyne (2002) discuss, the social and leisure benefits of a museum visit constitute a form of value in their own right. However, we suggest that the leisure dimension alone may provide an insufficient justification for a purposefully designed science learning environment.

Does fun trump learning?

Learning 'for fun' has been investigated in museums, highlighting the importance of learning being enjoyable (Packer and Ballantyne 2004). 'Having fun' was particularly important to Linda, who when asked before the visit about her hopes for the museum trip responded "enjoyment, obviously", later adding " ... and having a good time and fun and things like that". Notably, for Linda, having fun and learning science were not necessarily positively linked. For example, she worried that Darren's school teachers might "push" him too hard, to the point where he loses enjoyment for science.

All families appeared to value and experience aspects of their visit as 'fun'. However, only Kayefi's family (discussed in the following section), appeared to transform 'fun' into 'learning' (or, more specifically, learning with a clear exchange value). While research by Sue Allen (2004) suggests that fun and learning work together in hands-on, interactive galleries in ISLEs, our findings suggest that interactive galleries may not represent the same science learning opportunities to all families. Contrary to our expectations, it was noted that family talk and discussion was particularly limited in the large 'hands on' interactive gallery. In this area we recorded the fewest conversations within families, as children rushed off excitedly on their own to try out the activities. The space was also very noisy, reducing opportunities for questioning or discussion.

As argued above, the reliance on discussion-as-learning within the museum suggests that when opportunities for social learning are reduced, levels of learning among museum visitors are likely to be limited. The following extracts illustrate this:

Darren and his friend don't seem to try to figure anything out about the interactive apart from how to get it to 'do' whatever the 'thing' is, e.g. make a loud noise, throw a ball, ... etc. They do not talk about what is happening, or why. Linda does not read about the interactive or what they're supposed to be about. The boys just 'do' the 'thing' and leave. 
If they can't 'do' it, Darren gets very frustrated, shouts a lot and Linda goes to help him. ... once the boys feel they have 'won' [the game] they move on.

Notably, opportunities for reflection, whether through discussion or not, were also limited within the interactive gallery, with families racing quickly from one exhibit to the next. Collective family engagement with exhibits appeared more limited in this gallery than in other galleries. The following fieldnotes are typical of parent-child behaviour in this gallery:

As time goes on Tanisha (mother of Damis) yawns and is no longer reading or interacting, rather, she is watching the kids from distance.

Interactive exhibits have been promoted within the field of informal science education as facilitating science learning and engagement, for instance helping visitors to develop both general (e.g. Teixera 2008) and more specific, e.g. zoological, learning (Tunnicliffe and Laterveer-de Beer 2002). Our findings suggest, however, that while all families appeared to enjoy themselves, some families may be better equipped than others to derive science capital from interactive exhibits and galleries. Parents such as Tanisha and Linda are sidelined into passive roles in interactive galleries. As others such as Heath, Lehn and Osborne (2005) have suggested, while interactive science exhibits may afford certain learning opportunities, these are limited both in terms of the kinds of learning and kinds of interaction afforded. Our findings suggest that without facilitation to draw reflection and learning from the interactive exhibits (as discussed later in relation to Kayefi's family learning practices), despite having fun the families we observed struggled to learn in the interactive gallery.

Consequently, fun may be a necessary but insufficient condition of learning in an interactive science gallery. Fun may 'spark' an initial interest in a subject, but additional facilitation will be required to continue the interest or learning (Hidi and Renninger 2006). We now move on to discuss ways in which additional meaning and value (particularly in relation to science learning) might be developed through such visits.

\section{'Meaningful' visits: generating science learning and exchange value from visits}

Museums seek to provide a range of benefits and different forms of value to visitors and society, but, as John Falk (2004) discusses, they are also often positioned as vehicles for promoting science learning and science engagement. Currently, there is a prominent discourse within the informal science learning sector which seeks to demonstrate and evidence how museums can promote science learning, engagement and participation (Falk et al., 2012). Next, we discuss the ways in which families appeared to generate exchange value through their visits, particularly in 
relation to (science) learning. Only Kayefi's family typified this type of visit to any great extent although some aspects could be found across all families' visits.

All families identified 'learning' as one of their motivations for taking part in the museum visit, although it vied with 'having fun', as discussed above. Most parents explained that they hoped that either they themselves or their child would 'learn something' as a result of the visit. For example, in their pre-visit interviews, Tanisha and Gan explained:

Um ... well I just want Damis to gain something knowledgeable from it. You know ... um, how important science is, and you know changes it's made in life. So I guess once he goes away with that sort of knowledge then I'll be happy (Tanisha, Damis' mother). We want to see how does things work, you know? Because most things, we don't know how they work. (Gan, Bataar's father).

However, only Kayefi and her family seemed to have clearly fulfilled their learning goals from the visit. Kayefi stood out in terms of being able to articulate what science she had learnt from her visit. For example, Kayefi talked about how one of the science shows had helped her to better understand a topic about hydrogen that she had found difficult in class:

... in class we were doing the same thing [as in the show] ... first, I didn't understand it the way she [teacher] was saying it [in class]. And then later on when I went there [to the museum] ... Yeah [I understood]. [...] I'm happy cos ... and I learnt a lot, so now I know ... I use what I learnt there in class"

Although Bataar, Damis, Darren and Esrin had enjoyed their visits, they were unable to articulate or explain what they had learnt at the museum and were unable to link the science they had experienced in the museum with the science they learnt at school. For instance, Damis asserted in his post-visit interview that there was no connection at all between the science he studied at school and the science he had encountered in the museum. Despite saying that it was his favourite part of the visit, Bataar also struggled to remember exactly what he had done in the interactive gallery (“Um ... I don't think I remember"). Photographic prompts were used in the post-interviews to explore students' memories of the visits and to elicit any links between the science they encountered at school and in the museum - yet these failed to elicit any more links or recollections.

Interviewer: And is there anything you learnt at the Museum that's helped you with your school science?

Bataar: $\quad$ No.

Interviewer: So was it a different sort of science there to what you learn at school? Bataar: $\quad$ Yeah. 
Interviewer: What sort of topics are you learning about like last term, this term in science?

Bataar: $\quad$ Like um ... particles and like compounds, atoms. Yeah.

Interviewer: Mm, so you didn't see anything in the museum that related to that? Bataar: $\quad$ No.

Damis, Esrin and Darren also all struggled to remember particular aspects of the visit, even with the photographic prompts:
Damis: I don't remember seeing this.
Interviewer: Must have liked it, you took a picture?
Damis: $\quad$ I can't remember doing that.

Interviewer And do you remember what you had to do there?

Esrin I forgot.

So how did Kayefi's family manage to derive so much more learning, and transferable capital that enabled Kayefi to improve her engagement with and understanding of school science? We now identify and discuss two main ways in which families were able to make and derive meaning from their visits through: (i) leveraging pre-existing capital to facilitate engagement and learning; and (ii) making links between their own cultural backgrounds and the science in the museum.

\section{Leveraging existing capital.}

Kayefi's family stood out in that they preferred to 'do their own thing' within the museum, rather than take part in facilitated sessions. For example, unlike the other families, they did not do most of the object trails or facilitated activities on offer and they only consulted their lanyards once. Kayefi's family were adept at using self-directed activities within the museum and were the only family to record a successful experience at the 'meet a scientist' encounter. We suggest that this is largely because they possessed more capital than other families and experienced a closer alignment between their own and the institutional habitus, particularly in terms of their active approach to learning, which seemed close to the behavioural assumptions made about the 'ideal' visitors to the ISLE. Consequently they were able to leverage and facilitate more learning during their visit.

Kayefi's family possessed greater pre-existing cultural/ science capital and an educationally-aligned family habitus, which marked them out from the other families. Kayefi described her parents as "they're hands on, they care about my education a lot." Mr and Mrs Ogwu adopted a parenting style akin to the 'concerted cultivation' that Annette Lareau (2003) 
identifies as characteristic of many US white, middle-class parents, and which one of us (Archer 2010) has noted previously among the white and minority ethnic middle-classes in the UK. The interviews revealed how Kayefi's parents were proactive in seeking to support their daughters' attainment at school financially (e.g. investing in study guides) and culturally, actively fostering a 'learning habitus' within the family. Mrs Ogwu also carefully monitors her children's attainment and maintains regular contact with teachers, saying "I'm involved, yeah ... I always require feedback from the teachers", approaches which have been found to be less common among working-class and some minority ethnic families (Lareau 2002).

As Kayefi explained, her family are strongly focused on education and always seek to maximise the learning from any opportunity or activity:

"OK, as a family we do fun stuff, not something where you just learn stuff [...] but when we go cinema, my parents ask us 'What have you learnt from that?' Like In Toy Story my dad said 'What have you learnt from that' - we've learnt always stick together, never give up on each other and work as a team.

Like other migrant parents, such as those mothers studied by Reay (1998), Mr and Mrs Ogwu valued education as a means for their children to become socially mobile. This strongly focused family habitus was a clear source of motivation for Kayefi, who recognised the importance of learning and 'doing well' at school ('I don't want to disappoint my mum especially, cos I know what she's done for me, she's done a lot for me"). Kayefi's mother was particularly strongly supportive of science, because she saw it as contributing to modern life and societal improvement. In her pre- and post- interviews and during the visit, Mrs. Ogwu explained at length how she wanted the visit to inspire her daughters and to help them to appreciate the effort and resources required for everyday life, like generating water and electricity. She greatly respected those who have made the world a 'better place' through science and technology, relating this to issues in Britain and in Africa. In her post-visit interview, Kayefi agreed that her family had learned a lot from the visit ("we did learn a lot, and we see how science does help the world"). Kayefi also explained how she and her sisters were now more eco-conscious in their everyday lives too. In this respect, the alignment of the family and museum habitus facilitated science learning (particularly in relation to the museum's agenda to convey the science in everyday life and to promote environmental learning).

The family typified the 'ideal visitor' of the museum through their constant questioning and discussions around exhibits. For example, Kayefi's parents regularly posed questions and encouraged their children to offer potential answers and explanations, as exemplified by the following field note extracts: 
Gallery 2: Kayefi's mum explains how an engine works. Mum calls Kayefi back to the glass case with a model of DNA in it, saying “it's very, very important”. Kayefi replies "ah, we done this at school". Kayefi spots a scanning machine and goes over to it. Her dad asks questions and they talk about its uses (Kayefi says "they use this for cancer nowadays ... it's a brain, cancer thingy scanner"). Kayefi reads out the various information signs. On the mezzanine, Mum does some explaining about vehicles used in WW2 and about the loom, explaining how it is used for weaving cloth.

Kayefi's family were not the only ones to exemplify this approach, although they were the only family for whom this was a consistent characteristic of their engagement. Other parents did try to ask questions around particular activities or exhibits, with varying degrees of success. For example, Linda (Darren's mother) tried to ask the boys questions during the opening facilitated activity ("what else can you think of?") However, Linda also answered many of these questions herself, offering potential explanations. She also answered prompt questions posed by facilitators to Darren and Kuzay, with the upshot that the boys rarely answered questions themselves.

Kayefi's family engaged with the science content of the exhibits more actively than other families. For example, fieldnotes and photographs record all family members stopping at exhibits and reading the accompanying text/ signs with interest. As Mrs Ogwu explained, she not only read the labels on exhibits herself, but called over other family members to do the same. Kayefi's father also photographed a number of signs (with lots of explaining text on).

Kayefi's family were able to easily use and navigate the written information about exhibits, but this was not the case for all families. As discussed earlier, some family members were unfamiliar with particular language used in some descriptors. As Darren commented in his post-visit interview about written exhibit explanations, “I didn't understand half of it. There's like so much words that I just don't get. It's like weird").

We interpret Kayefi's family's apparent greater 'ease' within the museum as due to a closer alignment between their family habitus and the institutional habitus. Although they had never visited a Science Museum before, they do go on family outings to city farms, zoos and so on. Their pre-existing educational capital (e.g. Mr Ogwu's degree) contributes to a family habitus that is well aligned with the learning approach and institutional habitus of the museum, enabling the family to operate like a "fish in water", which "does not feel the weight of the water and it takes the world about itself for granted" (Bourdieu and Wacquant 1992, p.127). Consequently, the family appeared more confident and expert in navigating their visit and is better able to access and capitalise on potential science learning.

Learning science through making connections. 
As discussed earlier, although there was often a profound disconnect between the life-worlds of the families and the museum, some family members were still able to generate moments of connection between their own lives and identities and the museum content. For instance, in one of the galleries, Kayefi and her father spent some time looking at (and photographing) and old medical scanning machine. Kayefi explained in her post-interview that her father not only took some time to explain medical advances at this exhibit but also told her, for the first time, that he had previously been scanned ("My dad just mentioned it then that he's been scanned"), highlighting a personal connection to the technology.

Kayefi's family were also particularly successful in generating their own cross-cultural meaning-making from exhibits (Dawson 2014). For instance, the family spent some time in front of a glass case titled 'foreign ploughs'. They discussed which countries the different ploughs came from and Kayefi's mother related objects in the glass case to the family's African heritage and her own childhood experiences (e.g. "That's what they use in Germany and that's what they use in Africa - elephants"). Similarly, in the interactive gallery, Kayefi's mother used crosscultural examples to interpret the pumping water interactive. As Kayefi explained in her postvisit interview:

"cos it's different there [...] yeah like before she [mum] goes to school she used to have to do [clean] the whole house, so she woke up early at 5. And then she'll go and go to the river, go get water, and then come back and get water (inaudible) and then she'll bath and then she'll go again to get water for the whole family to use to bath. So then it was different, wasn't just turn on the tap".

The three girls were highly engaged by the linking of their mother's personal narrative with the museum exhibit, with one sister commenting "Must have been a really hard life".

Kayefi's family were not the only family to engage in cross-cultural meaning-making. Other families also found some points of recognition between their own lives and the exhibits. For instance, Esrin and her father became more animated in the agricultural gallery than anywhere else, as the following notes record.

Esrin's father says 'tractor' several times and talks about farming with Esrin. Dad gets out his phone and starts looking for pictures of the tractor on his own father's farm. They show me pictures of the farm in Turkey, the sheep they had, his father. They go around the first two 'rooms' of the agriculture gallery (before the workshop space) in detail, looking at all the dioramas and the objects, remarking on scythes, tractors, sheep and so on. Esrin says they all use tractors back home and even her mum could drive one. 
In her post-visit interview, when looking at photographs of their time in this gallery, Esrin recounted:

"That's when my dad was talking ... that's what they do in their country ... we call it (Turkish word) ... my mum used to work there [on farm] when she was young [...] My dad, he got really impressed to see that - that's why he took his phone out... But that was really cool, that was really cool. I learnt a lot of stuff because it shows like how it was"

Being able to bridge between scientific knowledge and personal, familial or community knowledge is increasingly understood to be an important part of science learning, particularly for people from disadvantaged backgrounds (Barton and Tan 2009). Such moments had a symbolic value in that they provided families with the opportunity to see themselves within the museum and, potentially, to develop an aspect of 'science identity' (Carlone and Johnson 2007). While families were only sometimes able to draw on their own knowledge to connect with exhibits and not always with success (as Linda's encounter with the 'parturition chair' exemplifies), echoing the work of Glen Aikenhead (2006), our findings suggest that cross-cultural learning, or funds of knowledge approaches, may provide valuable ways to broaden ISLE notions of 'ideal' visitors and help to design learning opportunities for a wider range of visitors.

\section{Discussion/ Conclusions}

There were many positive aspects to the museum visits. All five families who took part agreed that their visit had been fun and enjoyable. Each family derived some intrinsic benefit from their visit, particularly as valuable social bonding time and the excitement of a 'special' day out. We also found evidence that one family had derived some exchange-value from the visit, with demonstrable science learning, increased levels of personal motivation and some changed behaviours (e.g. more 'eco-friendly' behaviours). However, based on our analyses, we suggest that the predominance of 'fun' as a centrally defining aspect of a visit, does not necessarily guarantee wider social benefits, such as social inclusion and/or science learning. Moreover, 'fun' visits do not necessarily provide evidence for the wider value of ISLEs, which may be particularly important given their status as publically funded institutions.

Moreover, we suggest that our findings underline how, although 'non traditional' families may enjoy their visits, this enjoyment does not necessarily mean that barriers to inclusion, participation and engagement have been overcome. As we have discussed, all five families experienced some aspects of their visits as 'disorientating' - and we have argued that these issues are amplified in the case of socially disadvantaged families due to the greater mismatch between 
family/personal and institutional habitus. In other words, the contrast between ISLEs' 'ideal' visitor and the 'different' visitors from our five families was significant.

The uneven social distribution of habitus and capital means that some families are better placed than others to derive exchange-value from museum visits. Kayefi's family got more out of their visit because they possessed greater levels of capital and because their habitus was more closely aligned with the institutional habitus. Hence they were able to leverage more (and wider) value from the visit. We suggest that the museum we studied was not unique or different in this respect - rather, we suggest that the five families experiences reported here may raise questions of how ISLEs in general might be able to better support visitors with less capital and less well aligned habitus? In particular, we ask - where should the locus for change be located? Visitors or institutions? As one of us has previously argued in relation to widening participation initiatives in higher education (Archer, Hutchings and Ross 2003), there is an inherent inequality within social inclusion projects that seek to change 'non-traditional' groups to fit an unchanged institutional offer. Such efforts fall into the trap of 'blaming' the disadvantaged and failing to acknowledge or address unequal power relations and the role of the institution in perpetuating participation inequalities. With this point in mind, and based on the findings discussed here, we suggest that the following reflective points may be useful to help ISLEs that are interested in developing their inclusive practice:

How does an ISLE help to de-mystify the institutional habitus and share unspoken norms and values with diverse visitors?

An introduction and orientation space, specifically designed for 'first time' visitors, could be used to offer a range of resources for families to help them understand and navigate the institution. Resources might include short activities aimed at stimulating discussion and engagement, explaining why these are useful approaches to employ. Resources could usefully summarise ageappropriate activities and things to do and would ideally be provided in a range of languages. The orientation space should be designed with non-traditional visitors in mind. As suggested by Rahm and Ash (2008), it would be essential to ensure that staff within the orientation space (but also in the wider institution) are trained to work with families and groups who are outside the 'typical' visitor profile. 
How does an ISLE ensure that all social groups and communities can feel a sense of ownership and belonging within the institution? How is an inclusive environment signalled through language, knowledge, culture and visual representations?

Broadening the scope of the 'imagined' or 'ideal' visitor may be an important step in being able to deliver science learning opportunities that are more sensitive to difference and supporting a diverse range of visitors than our findings suggest is currently the case. Conducting an institutional audit to review language practices across the ISLE would be appropriate (to check accessibility for both foreign language speakers and English speakers). Provision of written and audio resources in a range of languages throughout the ISLE may help to include a wider range of visitors both practically and symbolically (as a signal of who is welcome, who is 'normal'). Touch screen descriptions of key objects in a range of audio and written languages could be helpful. Ensuring a breadth and diversity of cultural representations within ISLEs would also be important and relevant for fostering an inclusive environment. This might be achieved through better linking of exhibits to diverse cultural and national contexts.

How does an ISLE create opportunities for, and support visitors to engage in, hybrid/ crosscultural meaning making? How does an ISLE help visitors to link their experiences within the museum to their own interests, knowledge, values and experiences?

ISLEs might usefully explore and develop resources and approaches to help support and encourage families to make links between their own backgrounds and experiences and the exhibits. Orientation spaces should provide multilingual resources for visitors and parents, explaining how to help support/scaffold visits to help 'make the most' of a visit.

As discussed by Gutwill and Allen (2010), the use of techniques such as 'juicy questions' might also be useful here - particularly where such questions are used to facilitate cross-cultural meaning-making. As suggested elsewhere, developing science learning opportunities within ISLEs that function as a third space where multiple knowledges are bought into play to develop science learning can create valuable and positive science experiences, especially for people from disadvantaged backgrounds (Barton and Tan 2009). As such, and in line with arguments made by Aikenhead (2006) and Barton and Tan (2009), we suggest that designing science learning environments, whether in schools, museums or online, that provide opportunities for people to build links between their homes, personal lives, communities and science are important, not least for making more science relevant to more people. In the follow-up interviews, two parents (Linda, Darren's mother and Mrs Ogwu, Kayefi's mother) both suggested that they would 
appreciate the provision of spaces for reflection, in order to help children to reflect and on and consolidate what they had experienced.

How is an ISLE providing a range of marketing messages that connect with different, diverse audiences, without Othering disadvantaged groups?

As discussed in this article, all the families valued the visit as an opportunity for spending quality family time together. As Damis reflected after his visit, if he were to repeat the experience: 'I'd bring more of like my friends [and ...] I'd bring like more of the family members that loves going out a lot, and like feel how it is to be a family". There may be opportunities for ISLEs to flag how they might be well-placed contexts for enjoying 'family time'.

ISLEs in the UK might also reflect on how they address issues such as voluntary donations and the structure of cafes, entrance halls and shops (Welsh and Wynne 2013), with regard to whether these aspects of the visit are premised on a particular, classed configuration of the 'ideal visitor, and are disproportionately off-putting for less affluent visitors. As Esrin reflected in her postvisit interview, the entrance barriers and staff (who ask each visitor for a donation upon entry) could be off-putting:

Interviewer: And is there anything else you feel like you should tell me before you go back to class?

Esrin: $\quad$ Um ... I would just like them to change ... you know when you go in?

Interviewer: Uhuh.

Esrin: $\quad$ That bit. Just ...

Interviewer: The bit when you go in?

Esrin: $\quad$ Yeah that doesn't make it like want you to go in.

In sum, the five families who took part in the visit all enjoyed their day out at the science museum. However, as this small, exploratory study indicates, there is still more than needs to be done if the sector is to retain such visitors and ensure that they are able to leverage greater capital - but particularly in relation to science learning - from their visits. Moreover, it is also important to remember that in addition to challenging inequitable contexts within an ISLE, the issue of how to improve and widen access to ISLEs for diverse social groups still remains. That is, the families who we followed on this visit had not visited museums like this before and are unlikely to have visited had it not been for the project in question. This remains a key challenge for educators and professionals within and beyond ISLEs.

\section{Acknowledgements}


The Enterprising Science project is funded by BP and conducted in partnership between King's College London and the Science Museum. We extend our thanks to all the participating schools and students.

\section{References}

AAUW (2010). AAUW annual report. Washington: AAUW.

Aikenhead, G. (2006). Science education for everyday life: Evidence based practice. New York and London: Teachers College Press.

Allen, S. (2004). Designs for learning: Studying science museum exhibits that do more than entertain. Science Education, 88, S17-S33. doi: 10.1002/sce.20016

Anthias, F. (2001) New hybridities, old concepts: the limits of 'culture'. Ethnic and Racial Studies 24(4): 619-41.

Archer, L., Hutchings, M. And Ross, A. (2003) Higher Education and Social Class. London, RoutledgeFalmer.

Archer, L., DeWitt, J., Osborne, J., Dillon, J., Willis, B., \& Wong, B. (2010). "Doing" Science Versus "Being" a Scientist: Examining 10/11-Year-Old Schoolchildren's Constructions of Science Through the Lens of Identity. Science Education, 94(4), 617 - 639.

Archer, L., DeWitt, J., Osborne, J., Dillon, J., Willis, B., \& Wong, B. (2012). Science Aspirations, Capital, and Family Habitus: How Families Shape Children's Engagement and Identification With Science.

American Educational Research Journal, 49(5), 881-908

Archer, L., Dewitt, J. and Willis, B. (2013). Adolescent boys' science aspirations: Masculinity, capital and power. Published online in Journal of Research in Science Teaching, 51 (1), 1-30.

Ash, D. (2003) Dialogic inquiry in life science conversations of family groups in a museum. Journal of Research in Science Teaching, 40(2), 138-162.

Ash, D. (2004). Reflective scientific sense-making dialogue in two languages: The science in the dialogue and the dialogue in the science. Science Education, 88(6), 855-884. doi: $10.1002 /$ sce. 20002

Bamberger, Y., \& Tal, T. (2008). An experience for the lifelong journey: The long-term effect of a class visit to a science center. Visitor Studies, 11(2), 198-212.

Barton, A.C. and Brickhouse, N. W. (2006). Engaging girls in science, in C. Skelton, B. Francis \& L. Smulyan (Eds.), Handbook of Gender and Education (pp. 221-235). Thousand Oaks, CA: Sage.

Barton, A. C., and Tan, E. (2009). Funds of knowledge and discourses and hybrid space. Journal of Research in Science Teaching, 46(1), 50-73. doi: 10.1002/tea.20269

Bell, P., Lewenstein, B., Shouse, A., W., and Feder, M. A. (2009). Learning science in informal environments: People, places, and pursuits. Washington D.C.: The National Academies Press.

Borun, M. (1999). Gender roles in science museum learning. Visitor Studies Today!, 3(3), 11-14.

Bourdieu, P. (1991). Language and symbolic power (G. Raymond and M. Adamson, Trans.).

Cambridge and Malden, MA.: Polity Press.

Bourdieu, P. (1998). Practical reason. Cambridge: Polity Press.

Bourdieu, P., and Passeron, J.C. (1990). Reproduction in education, society and culture (R. Nice, Trans. Second ed.). London, Newbury Park CA, New Delhi: Sage. 
Bourdieu, P., and Wacquant, L. (1992). An invitation to reflexive sociology. Chicago: University of Chicago Press.

Brickhouse, N., Lowery, O. \& Schultz, K. (2000) What kind of girl does science? The construction of school science identities. Journal of Research in Science Teaching, 37(5): 441-458.

British Science Association. (2006). Representations of science: Black and minority ethnic communities. London.

Carlone, H. B., and Johnson, A. (2007). Understanding the science experiences of successful women of color: Science identity as an analytic lens. Journal of Research in Science Teaching, 44(8), 1187-1218. doi: 10.1002/tea.20237

CBI. 2012. Learning to Grow: What Employers Need from Education and Skills. Education and skills survey 2012. London: Confederation for British Industry.

Charlesworth, S. (2000). Bourdieu, Social Suffering and Working-Class Life. Oxford: Blackwell.

Crowley, K., \& Jacobs, M. (2002). Building islands of expertise in everyday family activity. In G.

Leinhardt, K. Crowley \& K. Knutson (Eds.), Learning conversations in museums (pp. 333-356). Mahwah, NJ: Lawrence Erlbaum Associates, Inc.

Dawson, E. (2014). "“Not Designed for Us": How Science Museums and Science Centers Socially Exclude Low-Income, Minority Ethnic Groups." Science Education, 98(6): 981-1008.

Department for Education and Skills. (2004). Report on the Science, Technology, Engineering and Maths (STEM) Mapping Review. London: Department for Education and Skills.

Elias, P., and Jones, P. (2006). Representation of Ethnic Groups in Chemistry and Physics. London: The Royal Society of Chemistry and the Institute of Physics.

Falk, J. H. (2004). The director's cut: Toward an improved understanding of learning from museums. Science Education, 88(S1), S83-S96. Falk, J. H., and Dierking, L. D. (2010). The 95 percent solution. American Scientist, 98, 486-493.

Falk, J. H., Osborne, J., Dierking, L. D., Dawson, E., Wenger, M., and Wong, B. (2012). Analyzing the UK Science Education Community: The contribution of informal providers. London: Wellcome Trust.

Gago, J. (2007). Taking European knowledge society seriously. Brussels: European Commission, Directorate-General for Research.

Garibay, C. (2009). Latinos, leisure values, and decisions: Implications for informal science learning and engagement. The Informal Learning Review, 94, 10-13.

Gonzalez, N. (2013). Introduction: Theorizing practices. In N. Gonzalez, L. C. Moll and C. Amanti (Eds.), Funds of Knowledge: Theorizing Practices in Households, Communities, and Classrooms (pp. 1-28). Mahwah, New Jersey: Taylor and Francis.

Gutwill, J. P., and Allen, S. (2010). Facilitating Family Group Inquiry at Science Museum Exhibits. Science Education, 94(4), 710-742. doi: 10.1002/sce.20387

Harding, S. (1998) Is science multicultural?Postcolonialisms, feminisms and epistemologies (race, gender and science). Indiana University Press.

Heath, C., Lehn, D. V., and Osborne, J. (2005). Interaction and interactives: Collaboration and participation with computer-based exhibits. Public Understanding of Science, 14(1), 91-101.

Hidi, S., and Renninger, K. A. (2006). The four-phase model of interest development. Educational Psychologist, 41(2), 111-127. doi: 10.1207/s15326985ep4102_4

Irwin, A., and Michael, M. (2003). Science, social theory and public knowledge. Maidenhead and Philadelphia: Open University Press. 
Leinhardt, G., Crowley, K., and Knutson, K. (2002). Learning conversations in museums: Psychology Press.

Levin, A. K. (Ed.). (2010). Gender, sexuality and museums. London and New York: Routledge.

Miles, M. B., \& Huberman, A. M. (1994). Qualitative Data Analysis: An Expanded Sourcebook.

Newbury Park, Cal: Sage Inc.

OECD. (2012). Education at a glance 2012: OECD indicators. http://dx.doi.org/10.1787/eag-2012-en: OECD Publishing.

Packer, J., and Ballantyne, R. (2002). Motivational factors and the visitor experience: A comparison of three sites. Curator: The Museum Journal, 45(3), 183-198. doi: 10.1111/j.21516952.2002.tb00055.x

Rahm, J. and D. Ash (2008). "Learning environments at the margin: Case studies of disenfranchised youth doing science in an aquarium and an after-school program." Learning Environments Research, 11(1): 49-62.

Ramey-Gassert, L. (1996). Same place, different experiences: exploring the influence of gender on students' science museum experiences. International Journal of Science Education, 18(8), 903-912. doi: 10.1080/0950069960180803

Reay, D. (1998) Class Work. London, Falmer Press.

Reay, D. (2004). 'It's all becoming a habitus': Beyond the habitual use of habitus in educational research. British Journal of Sociology of Education, 25(4), 431-444.

Reay, D., David, M., \& Ball, S. (2001). Making a difference?: Institutional habituses and higher education choice. Sociological Research Online, 5(4).

Sandell, R. (2007). Museums, prejudice and the reframing of difference. London and New York: Routledge.

Sandell, R., Dodd, J. And Garland-Thomson, R. (2010). Preface. In R. Sandell, J. Dodd and R. GarlandThomson. Re-Presenting disability: Activism and agency in the museum. Abingdon \& New York, Routledge.

Smith, E. (2010). Do we need more scientists? A long-term view of patterns of participation in UK undergraduate science programmes. Cambridge Journal of Education, 40(3), 281-298.

Teixera, T. (2008). Launchpad: Summative Evaluation Report. London: Science Museum.

Tunnicliffe, S. D., and Laterveer-de Beer, M. (2002). An Interactive Exhibition about Animal Skeletons: Did the Visitors Learn Any Zoology? Journal of Biological Education, 36(3), 130134.

UK Comission for Employment and Skills. (2010). Skills for jobs: Today and tomorrow (Vol. 2: The evidence report). London: UK Commission for Employment and Skills.

Welsh, I., and Wynne, B. (2013). Science, Scientism and Imaginaries of Publics in the UK: Passive Objects, Incipient Threats. Science as Culture, 22(4), 540-566. doi: 10.1080/14636778.2013.764072

Wilson, R. (2009). The demand for STEM graduates: Some benchmarking projections. London: Council for Industry and Higher Education.

Zimmerman, H. T., Reeve, S., and Bell, P. (2010). Family sense-making practices in science center conversations. Science Education, 94(3), 478-505. doi: 10.1002/sce.20374 